\title{
Relationship between changes in mitochondrial function and hippocampal neuronal apoptosis after recurrent convulsion during developmental stage
}

\author{
YUEYING LIU, JIERU CHEN, MEIFANG JIN, ZHENHONG LI, TIAN TIAN, LILI LI and HONG NI
}

Neurology Laboratory, Institute of Pediatrics, Children's Hospital of Soochow University, Suzhou, Jiangsu 215003, P.R. China

Received July 24, 2017; Accepted April 20, 2018

DOI: $10.3892 /$ etm.2018.6147

\begin{abstract}
The aim of the present study was to establish a recurrent convulsion model during the developmental stage using inhalation of flurothyl, and to observe the relationship between the changes in mitochondrial function in hippocampal neurons and hippocampal neuronal apoptosis after recurrent convulsion. A total of 36 Sprague-Dawley male rats were selected and randomly divided into the control (NS) group and recurrentseizure (RS) group for $0,1.5,3,12$ and $24 \mathrm{~h}$. After the last seizure the rats were subdivided with 6 animals in each group. Rats in the seizure group inhaled flurothyl repeatedly to induce status convulsivus, 30 min once daily, for 7 consecutive days, while the same operation was conducted in the control group without inhalation of flurothyl. At each time-point after the last seizure, blood was taken from the heart, followed by decapitation and immediate removal of the brain. Half of the brain tissue was immediately fixed in $10 \%$ paraformaldehyde to prepare paraffin-embedded tissues for hematoxylin and eosin (H\&E) histological staining. Hippocampus was taken from the other half of the brain and stored at $-80^{\circ} \mathrm{C}$. Changes in mitochondrial membrane potential $(\Delta \Psi \mathrm{m})$ in hippocampal neurons were detected by flow cytometer. Dynamic changes of mitochondrial fusion and division-related genes, mitochondrial fusion protein 2 (Mfn2) and dynamin-related protein 1 (Drp1), in the hippocampus after recurrent convulsion were observed using reverse transcription-polymerase chain reaction (RT-PCR) and western blot analysis. The expression of caspase-3 and cytochrome $c$ (Cyt c) was determined by RT-PCR and western blot analysis. After successful establishment of the recurrent convulsion model in rats during developmental stage using flurothyl, H\&E staining results exhibited that in the CA1 region
\end{abstract}

Correspondence to: Dr Hong Ni, Neurology Laboratory, Institute of Pediatrics, Children's Hospital of Soochow University, 303 Jingde Road, Suzhou, Jiangsu 215003, P.R. China

E-mail: nihong17@163.com

Key words: recurrent convulsion, developmental stage, apoptosis, mitochondrial membrane potential, mitochondrial apoptosis, mitochondrial fusion and division of hippocampus in the NS group, karyopyknosis occurred in nucleus that was stained to be brown and yellow, and the expression peak of apoptotic cells mainly existed at $24 \mathrm{~h}$ after the last convulsion. RT-PCR and western analysis revealed that apoptosis-related gene caspase- 3 expression in the RS group was elevated at $1.5 \mathrm{~h}$ after the last convulsion, and lasted $24 \mathrm{~h}$ after convulsion. Detection results of mitochondrial $\Delta \Psi_{\mathrm{m}}$ revealed a significant reduction $1.5,3$ and $12 \mathrm{~h}$ after convulsion in hippocampal neurons of experimental rats, which reached the trough at $12 \mathrm{~h}$, and rapidly increased after $24 \mathrm{~h}$. The expression of Mfn 2 mRNA in the RS group was significantly lower than that in the control group, while the expression of Drp1 mRNA in RS group was distinctly higher than that in the control group. RT-PCR and western blot analysis revealed that, mitochondrial apoptosis-related gene Cyt $c$ expression was increased at $3 \mathrm{~h}$ after the last convulsion, and lasted $24 \mathrm{~h}$ after convulsion. Correlation analysis showed that the changes in mitochondrial function were closely related to neuronal apoptosis. The results of the study show that apoptosis exists in the hippocampus of rats after recurrent convulsion, which is closely related to the changes in mitochondrial function.

\section{Introduction}

Recurrent convulsion during developmental stage endangers the lives of children, affecting children's intellectual development and physical health (1). Convulsion has paroxysmal, recurrent and persistent characteristics and may be accompanied by abnormalities of corresponding cognitive, psychological and social behavior that may continue into adulthood, which incurs a heavy psychological and economic burden on the children, their family and society (2,3). Apoptosis is the main form of brain damage after recurrent convulsion (4). Among apoptotic death receptors, endoplasmic reticulum signals and mitochondrial signaling pathways, the mitochondrial pathway is an important pathway of apoptosis involved in central nervous system diseases (5). Therefore, it is always a hotspot to further study the pathogenesis of convulsion in order to explore a relatively safe and effective therapeutic approach.

\section{Materials and methods}

Animals. Thirty-six Sprague-Dawley male rats (2.5-3month-old; weighing $280 \pm 350 \mathrm{~g}$ ) were obtained from Beijing 
Vital River Laboratory Animal Technology Co., Ltd. (Beijing, China). The rats were kept in cages with controlled temperature and light cycles $\left(24^{\circ} \mathrm{C}\right.$ and $12 / 12$ light cycles). The humidity was $40 \%$ and free access to water and food.

Behavioral characteristics of flurothyl-induced recurrent convulsion in rats during developmental stage. The rats in the recurrent-seizure group were dripped with flurothylin in the experimental cabin. After 40-60 sec, onset of convulsion occurred, and rats were manifested by dysphoria, head nodding, jumping around, accompanied with scream, followed by skin mucous cyanosis, rigidity of limbs and spasm, namely generalized tonic-clonic seizure and other seizure behaviors at grade III or above as per Racine scoring criteria (Racine grade III: facial clonus, including spasm-like blink, beard moving, rhythmic mastication, rhythmic nod, forelimb clonus). Each attack lasted 4-5 min, followed by intermittence for 2 to $3 \mathrm{~min}$, and consciousness in the intermission of convulsion was not recovered. The rats in the control group (NS group) had normal activity without convulsive attack.

Main reagents. Bicinchoninic acid (BCA) Protein Assay kit (Beyotime Institute of Biotechnology, Shanghai, China); TRIzol Total RNA Extraction kit and reverse transcription-polymerase chain reaction (RT-PCR) kit (both from Tiangen Biotech Co., Ltd., Beijing, China); terminal deoxynucleotidyltransferase (TdT)-mediated dUTP nick end-labeling (TUNEL) kit (Roche, Basel, Switzerland); anti-glyceraldehyde 3-phosphate dehydrogenase (GAPDH), anti-caspase-3 and cytochrome $c$ (Cyt c) monoclonal antibodies and secondary antibodies (all from Cell Signaling Technology, Inc., Boston, MA, USA) were used in the present study.

Preparation of paraffin-embedded tissues. Paraffin wax sample was prepared by routine dehydration, paraffin dipping and embedding, followed by coronal serial section with a thickness of $5 \mu \mathrm{m}$. Three sets of adjacent slices containing hippocampal tissue were selected, and slides were coated with poly-lysine for anti-stripping. The slides were removed and placed in an incubator at $62^{\circ} \mathrm{C}$ overnight, followed by hematoxylin and eosin (H\&E) staining and in situ cell apoptosis detection.

$H \&$ Estaining. Paraffin section was treated by routine dewaxing and hydration, followed by rinsing with phosphate-buffered saline (PBS) for $3 \mathrm{~min}$, for a total of three times. The sample was stained with hematoxylin for $5 \mathrm{~min}$, faded with $1 \% \mathrm{HCl}$ and rinsed using double-distilled water for $5 \mathrm{~min}$, for a total of six times. The sample was blued with lithium carbonate saturated solution for 1 to $2 \mathrm{~min}$ and rinsed in double-distilled water for $5 \mathrm{~min}$, three times, followed by color separation using $80 \%$ alcohol and rinsing with double-distilled water for 5 min, for a total of three times. Subsequently, the sample was stained with eosin for $5 \mathrm{~min}$ and rinsed in double-distilled water for $5 \mathrm{~min}$, for a total of three times. Finally, dehydration, hyalinization and mounting using resin were conducted.

Detection of apoptosis. According to the instructions, paraffin sections were treated by routine dewaxing and hydration, followed by rinsing with PBS for $3 \mathrm{~min}$, for a total of three times. Then it was incubated with $1 \% \mathrm{H}_{2} \mathrm{O}_{2}$ at room temperature for $20 \mathrm{~min}$ to inhibit endogenous peroxidase, followed by rinsing with $\mathrm{PBS}$ for $3 \mathrm{~min}$, three times and digestion with $20 \mu \mathrm{g} / \mathrm{ml}$ protease $\mathrm{K}$ at $37^{\circ} \mathrm{C}$ for $20 \mathrm{~min}$. Subsequently, the sample was rinsed with PBS for $3 \mathrm{~min}$, a total of three times and incubated in TdT buffer solution for $10 \mathrm{~min}$. The sample was soaked in mixture (100 $\mu \mathrm{l}$ solution containing $1 \mu \mathrm{l} \mathrm{TdT}$ and $1 \mu$ Biotin-11-dUTP mixture) at $37^{\circ} \mathrm{C}$ for $90 \mathrm{~min}$ and rinsed by PBS for $3 \mathrm{~min}$, a total of three times. Tris-buffered solution was added at room temperature for $15 \mathrm{~min}$ to terminate the reaction. The sample was added with anti-avidin-horseradish peroxidase (HRP) immediate solution drip by drip at $37^{\circ} \mathrm{C}$ for $1 \mathrm{~h}$ and rinsed with PBS for $3 \mathrm{~min}$, three times, followed by coloration with diaminobenzidine (DAB) for 20 to $30 \mathrm{~min}$, after which it was washed using running water to terminate the reaction. At higher magnification (10x40-fold), three visual fields in the hippocampal CA1 region were randomly observed, and the mean was calculated as the apoptotic number in this animal.

Determination of hippocampus neuronal mitochondrial membrane potential $(\Delta \Psi m)$ after convulsion. Single-cell suspension of hippocampus was prepared with the concentration of cells as $1 \times 10^{9} / 1$. The JC- 1 working fluid was added into cell suspension to make the final concentration was $5 \mathrm{mg} / \mathrm{l}$. Then it was incubated at room temperature for $30 \mathrm{~min}$ in the dark, and the cell count was $1 \times 10^{4}$. The mitochondrial $\Delta \Psi \mathrm{m}$ was measured by using an excitation wavelength of $488 \mathrm{~nm}$.

$R T-P C R$ analysis. Tissues of different groups were extracted according to operation procedures of RNAiso Plus kit (Tiangen Biotech Co., Ltd., Beijing, China), and the purity and content of the extracted RNA sample were calculated. The samples were packed separately and stored at $-80^{\circ} \mathrm{C}$ for experimental use. The reverse transcription reaction liquid was prepared according to the scale on the instructions of PrimeScript ${ }^{\circledR}$ RT reagent kit (Tiangen Biotech Co., Ltd.) with gDNA Eraser and added with the corresponding RNA sample, followed by reverse transcription to obtain cDNA. The level of mRNA was detected according to the protocol of SYBR ${ }^{\circledR}$ Premix Ex Taq ${ }^{\mathrm{TM}}$ II (Tli RNaseH Plus) kit (Tiangen Biotech Co., Ltd.). The corresponding RNA primer sequences are shown in Table I.

Western blot analysis. Operations were conducted in accordance with the instructions of the Total Protein Extraction kit (Beyotime Institute of Biotechnology, Shanghai, China). The sample was added with lysate and centrifuged at 12,000 $\mathrm{x}$ g and at $4^{\circ} \mathrm{C}$ for $10 \mathrm{~min}$. The supernatant was collected, namely total protein. The concentration of protein was detected by BCA Protein Assay kit (Beyotime Institute of Biotechnology), and samples were packed separately and stored at $-80^{\circ} \mathrm{C}$ for reservation. The total protein extraction fluid was mixed well with $2 \mathrm{X}$ loading buffer $(100+4 \mu \mathrm{l} \beta$-mercaptoethanol) according to the proportion of $1: 1$, and then placed into a boiling water bath for $5 \mathrm{~min}$, cooled and stored in a refrigerator at $4^{\circ} \mathrm{C}$ for preservation. The appreciable proportion of SDS-PAGE separation gel was prepared according the molecular weight of the target protein, followed by solidification for approximately $1 \mathrm{~h}$, and then 5\% SDS-PAGE concentrated gel was prepared, followed 
Table I. Quantitative PCR analysis of primer sequences of related genes.

\begin{tabular}{lll}
\hline Gene name & \multicolumn{1}{c}{ Forward primer $\left(5^{\prime}-3^{\prime}\right)$} & Reverse primer $\left(5^{\prime}-3^{\prime}\right)$ \\
\hline Mfn2 & ATGTCCCTGCTCTTTTCTCGA & CTATCTGCTGGGCTGCAGGTA \\
Drpl & ATGGAGGGGCTGATCCCGGTC & TCACCAAAGATGAGTGTGTCG \\
Cyspase-3 $c$ & GAGGCCGACTTCCTGTATGC & TGACCCGTCCCTTGAATTC \\
GAPDH & GGTGATGTTGAAAAAGGCAAGAA & TGCTTGCCTCCTTTTCCA \\
& GCACCGTCAAGGCTGAGAAC & TGGTGAAGACGCCAGTGGA
\end{tabular}

Mfn2, mitochondrial fusion protein 2; Drp1, dynamin-related protein 1.

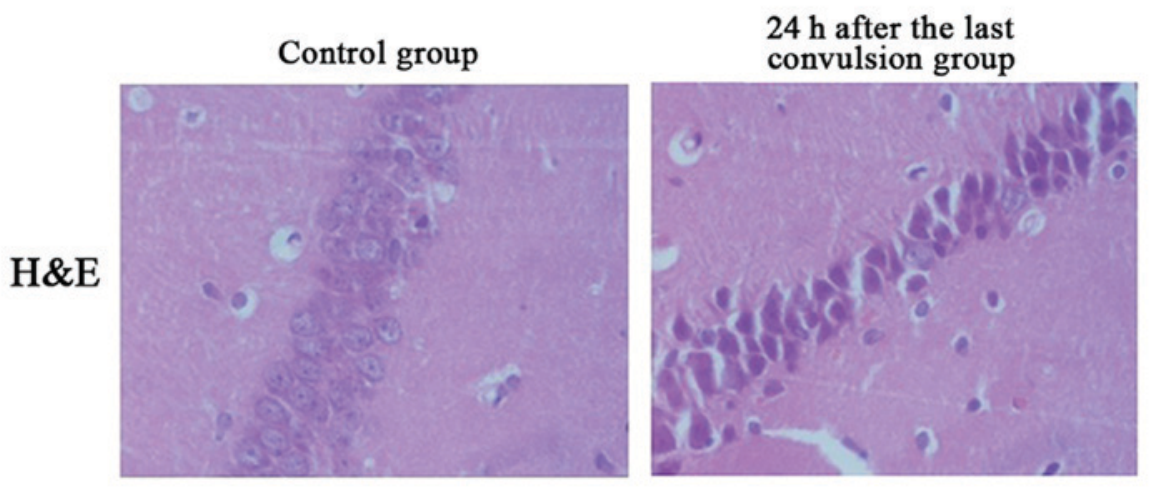

Figure 1. H\&E staining displays changes of CA1 apoptosis of hippocampus during developmental stage in control group and $24 \mathrm{~h}$ after the last convulsion group (x400 magnification).

by solidification for approximately $30 \mathrm{~min}$. The electrophoretic buffer was added, and the denatured protein sample was added into the loading sample well. The total protein content of each well was the same according to the concentration loading of protein. The sample was treated via electrophoresis under a constant pressure of $220 \mathrm{~V}$, until bromophenol blue was evident at the bottom of gel, and electrophoresis was stopped. The gel was cut off according to the molecular weight of target protein, and placed into transfer buffer.

A layer of polyvinylidene difluoride (PVDF) membrane and six layers of filter paper were cut according to the size of the gel. Firstly, PVDF membrane was soaked in carbinol for $10 \mathrm{sec}$, and then PVDF membrane and filter paper were placed into the transfer buffer. Then it was placed in the transfer apparatus according to positive pole - three-layer filter paper - PVDF membrane - gel - three-layer filter paper - negative pole, with attention to edge alignment to prevent blistering. Electrophoresis was performed under constant pressure of $110 \mathrm{~V}$ for $2 \mathrm{~h}$. PVDF membrane with protein was placed in 5\% skimmed milk powder and sealed on the table concentrator at room temperature for $3 \mathrm{~h}$. The sealed membrane was rinsed using Tween/Tris-buffered salt solution (TTBS) for $5 \mathrm{~min}$ and placed into rabbit anti-rat GAPDH, Mfn2, Drp1, caspase-3, Cyt $c$ primary monoclonal antibody (1:800; cat. nos. 5014, 9482, 8570, 9665, 4272; Cell Signaling Technology, Inc., Boston, MA, USA) with corresponding proportion, followed by incubation at $4^{\circ} \mathrm{C}$ overnight. The membrane was rinsed with TTBS three times, each for $10 \mathrm{~min}$, followed by placement into the corresponding goat anti-rabbit secondary polyclonal antibody (1:1,500; cat. no. 7074; Cell Signaling Technology,
Inc.). Then it was incubated on the table concentrator at room temperature for $3 \mathrm{~h}$ and rinsed with TTBS three times, each for $10 \mathrm{~min}$. The gel imager was started up to preheat for $30 \mathrm{~min}$. The reagents of $\mathrm{A}$ and $\mathrm{B}$ in the enhanced chemiluminescence (ECL) reagent box were mixed uniformly as the equal volume, followed by dropping on the PVDF membrane for full contact and developing avoiding light for $1 \mathrm{~min}$. By using filter paper, the excess liquid around the membrane was sucked, and the membrane was placed in the gel imager. The image was taken using dynamic integral model, and the results were observed. Image analysis was completed by Lab Works 4.6 professional image analysis software.

Statistical analysis. Experimental data were expressed as mean \pm standard deviation (mean $\pm \mathrm{SD}$ ). Experimental results were statistically analyzed by Statistical Product and Service Solutions (SPSS) 17.0 (SPSS Inc., Chicago, IL, USA) software. The t-test was adopted for comparison of mean between the two groups. One-way analysis of variance (ANOVA) was utilized for comparison of mean among multiple samples and the post hoc test was Dunnett's test. The t-test was used for pairwise comparison. $\mathrm{P}<0.05$ was considered to indicate a statistically significant difference.

\section{Results}

$H \& E$ staining. As shown in Fig. 1, in the control group, pyramidal cells in CA1 region of hippocampus were manifested by tight arrangement, distinct gradations, clear margin, transparent cytoplasm, elliptical or round cells, uniform distribution 
Table II. Dynamic changes of $\Delta \Psi \mathrm{m}$ in rat neurons after sustained convulsion.

\begin{tabular}{lc}
\hline Group & Mitochondrial $\Delta \Psi \mathrm{m}$ \\
\hline Control & $8.68 \pm 0.97$ \\
$0 \mathrm{~h}$ & $8.62 \pm 1.08$ \\
$1.5 \mathrm{~h}$ & $7.47 \pm 0.89$ \\
$3 \mathrm{~h}$ & $7.32 \pm 1.02$ \\
$12 \mathrm{~h}$ & $6.82 \pm 0.99$ \\
$24 \mathrm{~h}$ & $7.28 \pm 1.03$ \\
\hline
\end{tabular}

$\Delta \Psi \mathrm{m}$, mitochondrial membrane potential.

Table III. Correlation between changes in mitochondrial function and neuronal apoptosis.

\begin{tabular}{lcc}
\hline Group & $\begin{array}{c}\text { Mitochondrial membrane } \\
\text { potential }\end{array}$ & $\begin{array}{c}\text { Apoptosis } \\
\text { rate (\%) }\end{array}$ \\
\hline Control & $8.68 \pm 0.97$ & $1 \pm 2$ \\
$0 \mathrm{~h}$ & $8.62 \pm 1.08$ & $2 \pm 1$ \\
$1.5 \mathrm{~h}$ & $7.47 \pm 0.89$ & $18 \pm 5$ \\
$3 \mathrm{~h}$ & $7.32 \pm 1.02$ & $22 \pm 3$ \\
$12 \mathrm{~h}$ & $6.82 \pm 0.99$ & $32 \pm 4$ \\
$24 \mathrm{~h}$ & $7.28 \pm 1.03$ & $21 \pm 5$ \\
\hline
\end{tabular}

of chromatin in the nucleus and clear nucleoli. After recurrent convulsion, pyramidal cells in CA1 region of hippocampus were manifested by gradually scattered arrangement, cellular swelling and some cell fracture, followed by the characteristic apoptosis changes such as cells becoming smaller, margination and condensation of chromatin, karyopyknosis and hyperchromasia and extracellularhalos. The peak of changes was at $24 \mathrm{~h}$.

Dynamic changes of mitochondrial $\Delta \Psi m$ in rat neurons after sustained convulsion. As shown in Table II, mitochondrial $\Delta \Psi \mathrm{m}$ in hippocampal neurons of experimental rats were significantly reduced at 1.5, 3 and $12 \mathrm{~h}$ after convulsion, which reached a trough at $12 \mathrm{~h}$, and was rapidly elevated from $24 \mathrm{~h}[\mathrm{p}<0.05, \mathrm{p}<0.01(\mathrm{n}=6)]$.

RT-PCR results of mitochondrial fusion and division-related genes, Mfn2 and Drpl. The expression of Mfn2 mRNA in hippocampus tissue was significantly lower than that in the control group at 1.5, 3, 12 and $24 \mathrm{~h}$ after recurrent convulsion $(p<0.05)$, whereas that of Drp1 mRNA in hippocampus tissue was distinctly higher than that in the control group at 1.5, 3, 12 and $24 \mathrm{~h}$ after recurrent convulsion $(\mathrm{p}<0.05)$ (Fig. 2).

Expression of Mfn2 and Drpl proteins in each group. As shown in Fig. 3, the results of western blot analysis revealed that Mfn2 protein expression in hippocampus tissue was obviously lower than that in the control group at $1.5,3,12$ and $24 \mathrm{~h}$ after recurrent convulsion. By contrast, the expression of Drp1
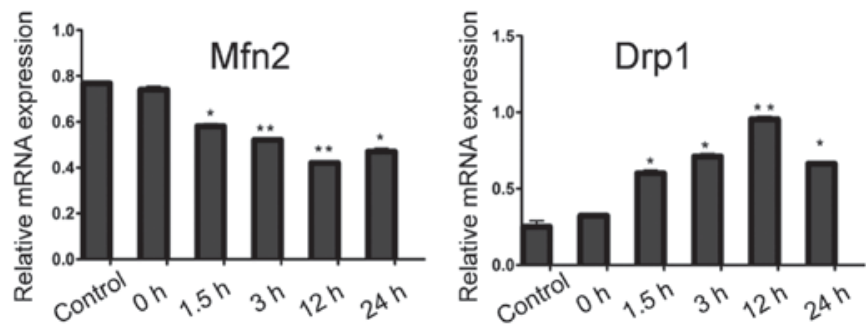

Figure 2. RT-PCR results of mitochondrial fusion and division-related genes, Mfn2 and Drpl. Compared with those in the control group, ${ }^{*} \mathrm{p}<0.05$, ${ }^{* *} \mathrm{p}<0.01(\mathrm{n}=6)$. Mfn2, mitochondrial fusion protein 2; Drp1, dynaminrelated protein 1 .

protein in hippocampus tissue was significantly higher than that in the control group at 1.5, 3, 12 and $24 \mathrm{~h}$ after recurrent convulsion.

$R T$-PCR results of apoptosis-related factors. Compared with that in the control group, caspase- 3 expression in the hippocampus of rats in convulsion group began to rise at $1.5 \mathrm{~h}$ after the last convulsion, and lasted $24 \mathrm{~h}$ after convulsion. The expression of Cyt $\mathrm{c}$ in hippocampus of rats in convulsion group was increased at $3 \mathrm{~h}$ after the last convulsion, and lasted $24 \mathrm{~h}$ after convulsion (Fig. 4).

Expression of caspase-3 and Cyt c proteins in each group. As shown in Fig. 5, the results of western blot analysis revealed that compared with that in the control group, caspase- 3 expression in the hippocampus of rats in the convulsion group began to rise at $1.5 \mathrm{~h}$ after the last convulsion, and lasted $24 \mathrm{~h}$ after convulsion. The expression of Cyt $c$ in hippocampus of rats in convulsion group was increased at $3 \mathrm{~h}$ after the last convulsion, and lasted $24 \mathrm{~h}$ after convulsion. The results indicated that the expression of apoptosis-related genes, caspase- 3 and Cyt $c$, were increased after the recurrent convulsion during the developmental stage, suggesting that apoptosis occurs in the early stage after recurrent convulsion.

Correlation analysis of changes in mitochondrial function and neuronal apoptosis. As shown in Table III, the changes of mitochondrial membrane potential were at different time-points, and apoptotic rates were also distinctly changed at the same time. It was evident that the change in mitochondrial function was closely related to neuronal apoptosis.

\section{Discussion}

The occurrence of convulsion is very complex, and although a great deal of research has been conducted, the mechanism involved remains unclear. Previous studies in China and foreign countries have revealed that apoptosis and necrosis are the main pathogenesis of neuronal damage after convulsion $(6,7)$. However, recent studies have found that mitochondrial function changes and apoptosis play important roles in the occurrence and development of convulsion (8-10). Neurons are non-differentiated cells, which cannot remove the damaged misfolded proteins and organelles through cell division; thus, they are especially sensitive to apoptosis and closely associated with many chronic nervous system diseases (11). 

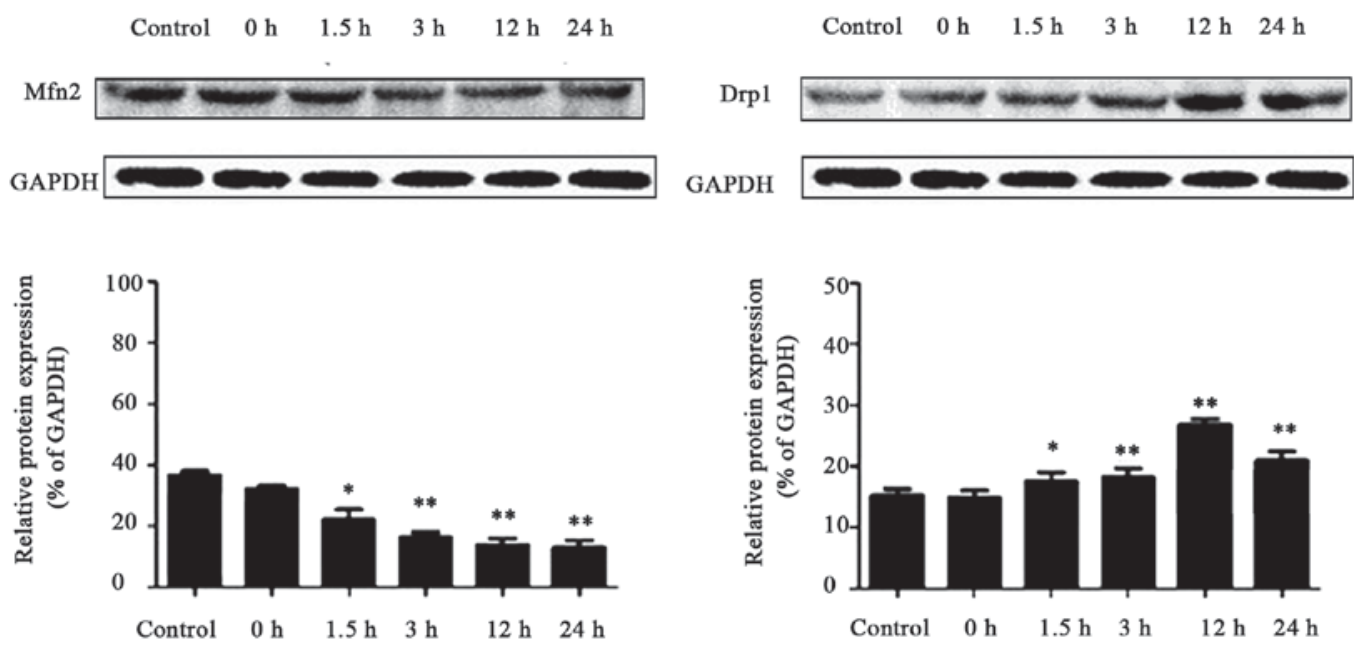

Figure 3. Expression of Mfn2 and Drpl proteins in each group. Compared with those in the control group, ${ }^{*} \mathrm{p}<0.05,{ }^{* *} \mathrm{p}<0.01$ ( $\mathrm{n}=3$ ). Mfn2, mitochondrial fusion protein 2; Drp1, dynamin-related protein 1.
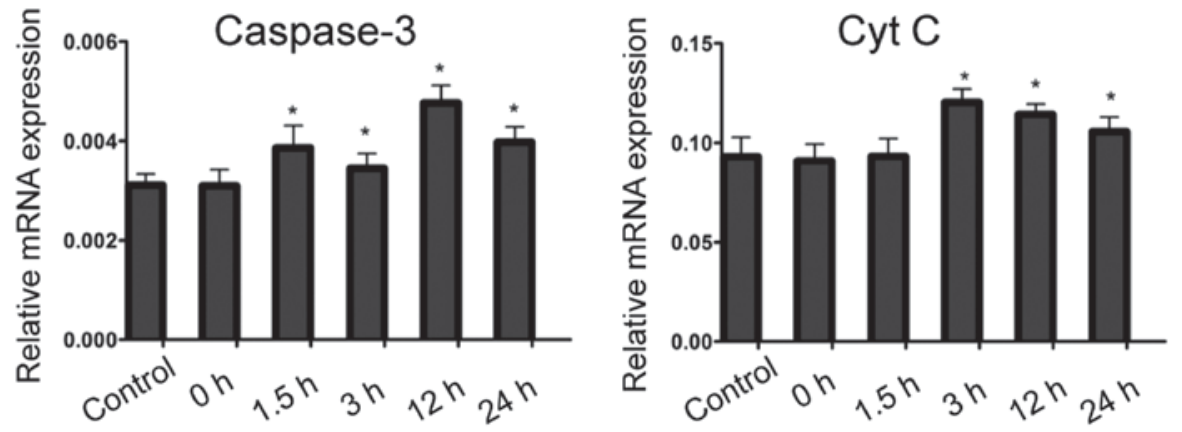

Figure 4. Detection of expression of apoptosis-related factors caspase-3 and Cyt c using RT-PCR. Compared with those in the control group, "p<0.05 (n=3). Cyt c, cytochrome $c$
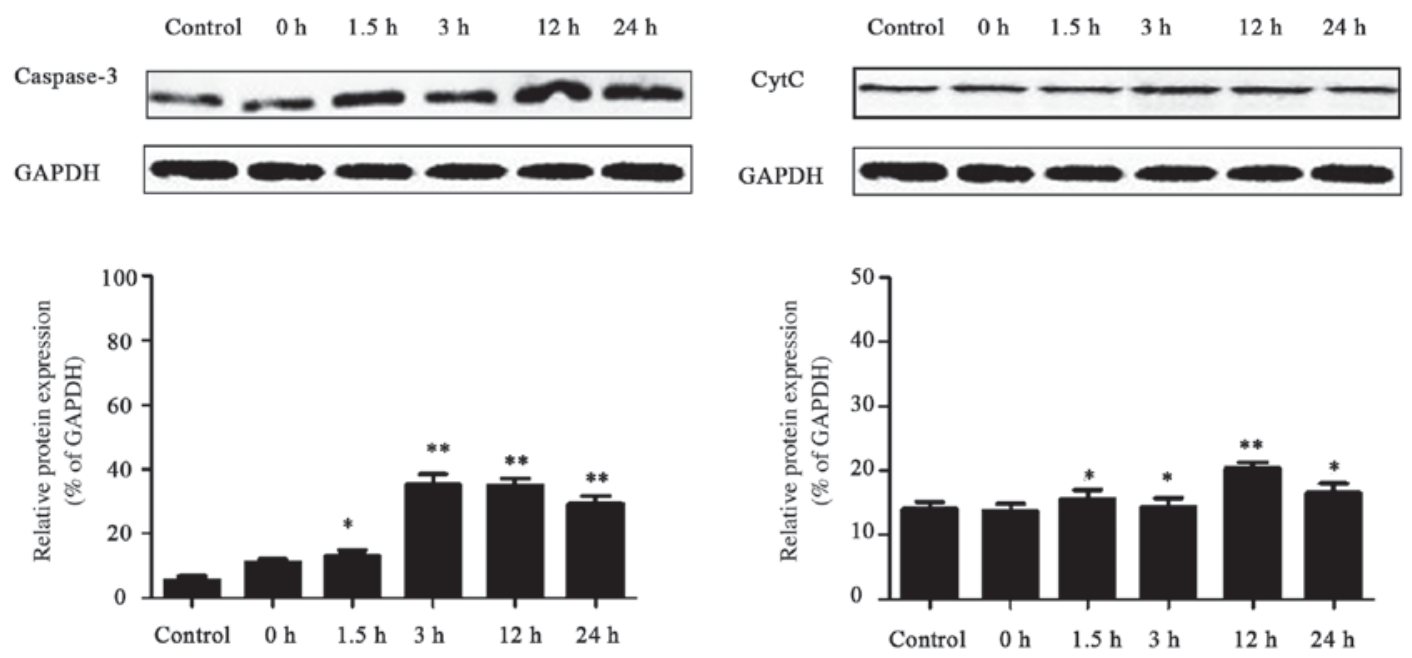

Figure 5. Expressions of caspase-3 and Cyt c proteins in each group. Compared with those in the control group, ${ }^{*} \mathrm{p}<0.05,{ }^{* *} \mathrm{p}<0.01(\mathrm{n}=3)$. Cyt $\mathrm{c}, \mathrm{cytoch} r \mathrm{me} c$.

Previous findings have indicated that apoptosis is programmed cell death induced by a variety of pathological and physiological stimuli, and whether or not apoptosis occurs in multiple cells, including neurons, is affected by many links in the upstream (12). Therein, the reduction of mitochondrial $\Delta \Psi \mathrm{m}$ and release of apoptosis-related factors are considered to be important links of apoptosis (13). $\Delta \Psi \mathrm{m}$ is the potential difference between the two sides of biofilm (14). The reduction of $\Delta \Psi \mathrm{m}$ causes the opening of the mitochondrial permeability transition pore, increase of nuclear permeability, release of ion and some proteins in mitochondrial matrix and disappearance of ion gradient across the inner membrane, thus forming a 
vicious cycle and resulting in a further decline in $\Delta \Psi \mathrm{m}$ until complete disintegration (15-17). After the mitochondrial permeability transition pore opening and the rupture of outer mitochondrial membrane, mitochondrial interstitial apoptosispromoting factor $\mathrm{C}$ is released to cytoplasm (18). Under the action of apoptosis-promoting gene, the assembly that promotes aspartic acid specific cysteine protease complex is formed, incurring apoptosis inevitably $(19,20)$. Thus, the reduction of mitochondrial permeability transition pore and the release of apoptotic factors are considered the early events of apoptosis.

In this study, flurothyl was used to induce recurrent convulsion in rats for seven consecutive days during developmental stage at eight days after birth (the 8th day). At 0, 1.5, 3, 12 and $24 \mathrm{~h}$ after the last convulsion at 14th day, the dynamic changes of mitochondrial fusion and division-related genes, $M f n 2$ and Drpl, in the hippocampus after recurrent convulsion and expressions of apoptosis-related genes (caspase-3, Cyt c) in rat hippocampus were detected by RT-PCR and western blot analysis. The changes in mitochondrial $\Delta \Psi_{\mathrm{m}}$ in hippocampal neurons were detected by flow cytometer, and expressions of apoptosis-related factors (caspase-3, Cyt c) were determined by western blot analysis eventually. The study aimed to investigate the changes in mitochondrial function and the role of apoptosis in brain injury after recurrent convulsion during developmental stage, so as to provide a new intervention target for clinical treatment of convulsion.

\section{Acknowledgements}

Not applicable.

\section{Funding}

No funding was received.

\section{Availability of data and materials}

The datasets used and/or analyzed during the present study are available from the corresponding author on reasonable request.

\section{Authors' contributions}

YL and JC were responsible for collection and preparation of paraffin-embedded tissues. MJ and ZL performed and analyzed H\&E staining. TT helped with PCR. LL and HN contributed to western blot analysis. All authors read and approved the final manuscript.

\section{Ethics approval and consent to participate}

The study was approved by the Ethics Committee of the Children's Hospital of Soochow University (Jiangsu, China).

\section{Consent for publication}

Not applicable.

\section{Competing interests}

There were no competing interests to declare.

\section{References}

1. Shinnar S, Pellock JM, Moshé SL, Maytal J, O'Dell C, Driscoll SM, Alemany M, Newstein D and DeLorenzo RJ: In whom does status epilepticus occur: Age-related differences in children. Epilepsia 38: 907-914, 1997.

2. Huang L, Cilio MR, Silveira DC, McCabe BK, Sogawa Y, Stafstrom CE and Holmes GL: Long-term effects of neonatal seizures: A behavioral, electrophysiological, and histological study. Brain Res Dev Brain Res 118: 99-107, 1999.

3. Chin RF, Neville BG, Peckham C, Wade A, Bedford H and Scott RC: Treatment of community-onset, childhood convulsive status epilepticus: A prospective, population-based study. Lancet Neurol 7: 696-703, 2008.

4. Roy H, Lippé S, Lussier F, Sauerwein HC, Lortie A, Lacroix J and Lassonde M: Developmental outcome after a single episode of status epilepticus. Epilepsy Behav 21: 430-436, 2011.

5. Sheppard E and Lippé S: Cognitive outcome of status epilepticus in children. Epilepsy Res Treat 2012: 984124, 2012.

6. Liu Z, Yang Y, Silveira DC, Sarkisian MR, Tandon P, Huang LT, Stafstrom CE and Holmes GL: Consequences of recurrent seizures during early brain development. Neuroscience 92: 1443-1454, 1999.

7. Gómez-Gonzalo M, Losi G, Chiavegato A, Zonta M, Cammarota M, Brondi M, Vetri F, Uva L, Pozzan T, de Curtis M, et al: An excitatory loop with astrocytes contributes to drive neurons to seizure threshold. PLoS Biol 8: e1000352, 2010.

8. Wang H, Yan WJ, Zhang JL, Zhang FY, Gao C, Wang YJ, Bond Law W and Tao L: Adiponectin partially rescues high glucose/high fat-induced impairment of mitochondrial biogenesis and function in a PGC-1 $\alpha$ dependent manner. Eur Rev Med Pharmacol Sci 21: 590-599, 2017.

9. Ouyang YB, Lu Y, Yue S and Giffard RG: miR-181 targets multiple Bcl-2 family members and influences apoptosis and mitochondrial function in astrocytes. Mitochondrion 12: 213-219, 2012.

10. January CT, Wann LS, Alpert JS, Calkins H, Cigarroa JE, Cleveland JC Jr, Conti JB, Ellinor PT, Ezekowitz MD, Field ME, et al; American College of Cardiology/American Heart Association Task Force on Practice Guidelines: 2014 AHA/ACC/HRS guideline for the management of patients with atrial fibrillation: A report of the American College of Cardiology/American Heart Association Task Force on Practice Guidelines and the Heart Rhythm Society. J Am Coll Cardiol 64: e1-e76, 2014.

11. Arends MJ and Wyllie AH: Apoptosis: Mechanisms and roles in pathology. Int Rev Exp Pathol 32: 223-254, 1991.

12. Schwartzman RA and Cidlowski JA: Apoptosis: The biochemistry and molecular biology of programmed cell death. Endocr Rev 14: 133-151, 1993.

13. Savill J and Fadok V: Corpse clearance defines the meaning of cell death. Nature 407: 784-788, 2000.

14. Falasca L, Bergamini A, Serafino A, Balabaud C and Dini L: Human Kupffer cell recognition and phagocytosis of apoptotic peripheral blood lymphocytes. Exp Cell Res 224: 152-162, 1996.

15. Fadok VA, Voelker DR, Campbell PA, Cohen JJ, Bratton DL and Henson PM: Exposure of phosphatidylserine on the surface of apoptotic lymphocytes triggers specific recognition and removal by macrophages. J Immunol 148: 2207-2216, 1992.

16. Yin XM: Signal transduction mediated by Bid, a pro-death Bcl-2 family proteins, connects the death receptor and mitochondria apoptosis pathways. Cell Res 10: 161-167, 2000.

17. Duchen MR: Mitochondria and calcium: From cell signalling to cell death. J Physiol 529: 57-68, 2000.

18. Zou H, Li Y, Liu X and Wang X: An APAF-1.cytochrome $c$ multimeric complex is a functional apoptosome that activates procaspase-9. J Biol Chem 274: 11549-11556, 1999.

19. Acehan D, Jiang X, Morgan DG, Heuser JE, Wang X and Akey CW: Three-dimensional structure of the apoptosome: Implications for assembly, procaspase-9 binding, and activation. Mol Cell 9: 423-432, 2002.

20. Desagher S and Martinou JC: Mitochondria as the central control point of apoptosis. Trends Cell Biol 10: 369-377, 2000. 